doi: https://doi.org/10.15407/microbiolj82.03.071

\title{
BACTERIOCINS OF SOME GROUPS OF GRAM-NEGATIVE BACTERIA
}

\author{
O.I. Balko, O.B. Balko, L.V. Avdeeva \\ Zabolotny Institute of Microbiology and Virology, NAS of Ukraine, \\ 154 Acad. Zabolotny Str., Kyiv, 03143, Ukraine \\ e-mail: oleksandrbalko@gmail.com
}

The results of gram-negative bacteria bacteriocins research have been analyzed. These killer factors are characterized by powerful antimicrobial activity, narrowly directed spectrum of action and safety for the macroorganism. Bacteriocins, especially produced by gram-negative bacteria, are investigated very differentially and, in most cases, insufficiently, the available information is not systematized. The present article focused on bacteriocins, which are active against phytopathogenic bacteria and can be used in crop production as independent biocontrol agents, as well as on the killer factors of marine microorganisms, which application in aquaculture is allowed only with their producer-strains.

Keywords: bacteriocins, phytopathogenic bacteria, crop production, marine microorganisms, aquaculture.

Bacteriocins are considered to be one of the most widespread natural agents of bacterial defense $[1,2]$. This large and quite diverse family of killer factors is characterized by storage stability and low toxicity to humans, but their narrow killer activity is limited to bacterium species closely related to producer strain [3, 4]. Bacteriocins are synthesized by the majority of gram-positive and gram-negative microorganisms [5]. However, in contrast to the killer factors of gram-positive bacteria, bacteriocins of gram-negative bacteria have not been sufficiently studied [6, 7]. Among the killer factors of gram-negative bacteria, the most carefully explored substances are colicins - bacteriocins of Escherichia coli [1, 8-10]. Thanks to a number of researches of foreign and Ukrainian scientists, bacteriocins of Pseudomonas aeruginosa (pyocins) [11-15] and Pectobacterium carotovorum (carotovoricins) are also well known [16-18]. At the same time, little is known about bacteriocins of phytopathogenic, marine, soil microorganisms, representatives of normal human and animal microflora and their closely related species $[19,20]$.

Today, bacteriocins attract attention as potential drugs, alternative to existing medicines for certain diseases $[6,21]$. In most cases, these killer factors are active against closely related bacterial species. Considering insignificant amount of side effects, it creates the necessary prerequisites for their use as narrow-spectrum antimicrobials [22, 23]. However, not only purified or partially purified bacteriocin preparations can find application. It is known that most bacteria secrete killer factors for competitive advantage in a particular environmental niche $[1,24]$. Therefore, bacteriocin-producing strains can become potential components of biological products for treatment and diseases prevention of plants, animals and even humans, since their use will contribute to elimination of pathogens from certain biotopes [22, 25]. Recent attempts to create genetically engineered bacteriocins, aimed at making these killer factors more usable, increase the possibility of widespread introduction of these substances in crop production, animal husbandry, medical practice, and food industry $[3,26]$.

\section{Basic concept about bacteriocins}

Bacteriocins are heterogeneous antibiotic-like substances, mainly of protein nature, synthesized by most bacteria and characterized by bactericidal action against representatives of phylogenetically close species of microorganisms $[1,8,9]$. This group of substances includes killer factors with different morphological and biochemical properties, molecular weight, activity spectrum and mechanisms of action: peptides, low molecular weight proteins, enzymes, phage-like structures, 
that are synthesized by defective lysogenic bacteria $[11,19,27]$. These substances are joined in a single family according to common features: bacteriocins are the primary metabolites of protein nature, which are synthesized on the ribosomes, released at the exponential growth phase, active against a rather narrow range of related bacteria, except for their own producer strains $[3,19,22]$. Other bacteriocinrelated groups of antimicrobials are antibiotics and bacteriophages [4, 28-32]. In contrast to bacteriocins, classical antibiotics are secondary metabolites of non-protein nature predominantly, not synthesized on the ribosomes, released at the stationary growth phase, have a broad spectrum of action, inhibit the growth of their own producer strains, and also affect eukaryotic cells $[3,13$, 20, 33]. High molecular weight bacteriocins are morphologically similar to bacteriophages, but have slightly lower molecular weight, do not contain nucleic acids and therefore are not capable of self-replication in bacterial cells $[6,12]$. When applied to a lawn of sensitive culture, high molecular weight bacteriocins form lysis zones, the intensity of which is reduced under dilution without the appearance of phage plaques, and these killer factors are not transferred from the formed zones to the fresh lawn of the indicator culture $[16,31]$.

According to producer strains, bacteriocins can be divided into two main groups: protein bacteriocins secreted mainly by Gracilicutes gram-negative bacteria, and peptide bacteriocins of Firmicutes - gram-positive microorganisms $[1,34]$. Bacteriocins of gram-negative bacteria can be divided into four substantially different groups: macromolecular (high molecular weight) bacteriocins, colicin-like (low-molecularweight) bacteriocins, microcins, and unclassified bacteriocin-like substances $[4,10]$.

High molecular weight bacteriocins (tailocins) are protein particles with molecular weight of about 1-10 MDa. They resemble tails of bacteriophages, as they are composed of sheath, core, baseplate and tail fibres $[35,36]$. Macromolecular killer factors affect sensitive cells by disrupting cell wall continuity [11]. Low molecular weight proteins of $20-100 \mathrm{kDa}$ are referred to colicinlike bacteriocins $[6,11,18,37,38]$. These killer factors are synthesized as two proteins, which subsequently function together as a protein subunit. One protein is actually bacteriocin, while the other is immunity protein [1]. Microcins are a group of simple proteins synthesized by Enterobacteriaceae family members, however, they have much lower molecular weight - less than $10 \mathrm{kDa}$ [39-41]. Most representatives of this killer factor group undergo posttranslational modification during maturation $[42,43]$. A number of substances isolated from gram-negative bacteria can be classified as bacteriocins, however, due to significant differences in structure, they do not belong to any groups described [14, 44]. An example of such substances can be bacteriocinlike inhibitory substances (BLIS) synthesized by marine gram-negative microorganisms, only a few of them are characterized in detail [19]. Other representatives are synthesized by Agrobacterium tumefaciens and Rhizobium leguminosarum tripholitoxins or RTX-type (from repeats in toxin) toxins of $R$. leguminosarum. Genome analyses of gram-negative bacteria revealed that some members of this group may also produce peptide bacteriocins, referred to as "gram-positive-like" peptide bacteriocins [20]. It should be noted that the classification of bacteriocins, especially synthesized by gram-negative bacteria, is currently at the stage of evidence accumulation [1, 4]. Therefore, the search and study of new substances in this group will help to form a clearer conception of the prevalence and importance of bacteriocins in the processes of inter-bacterial interaction.

\section{Bacteriocins of phytopathogenic bacteria}

According to data of the Food and Agriculture Organization of the United Nations (FAO), bacterial diseases cause the loss of about $30 \%$ of agriculture crop. Bacterial diseases of plants create great difficulties for crop production and horticulture [45-47]. The rhizosphere and plantassociated biotopes are densely populated by a large number of microbial species [48]. The ability of phytopathogenic microorganisms to survive at this bacterial diversity, as well as to interact with the host plant, is important factor for their ecological adaptation [20]. Under competition for nutrients, bacteria use different survival strategies. One of them is the synthesis of substances with antimicrobial properties, in particular bacteriocins, active against closely related bacteria that inhabit a certain ecological niche [10,49]. By affecting the survival of microbial cells and, even their virulence, bacteriocins are able to regulate the abundance of bacterial population [9]. It should be noted that the application of narrowly specific killer factors can be an effective strategy for bacterial diseases control, including pathogens of crops, against which even chemical pesticides are ineffective $[2,20,50]$. 
Potential use of bacteriocins for the regulation of phytopathogenic bacteria has been suggested by a number of researchers $[46,51,52]$. Other authors consider the application of bacteriocin-producing strains, in particular gram-negative bacteria, in the composition of biopreparations for crop production [53]. The application of these biological means for plant disease control will limit the use of chemical pesticides, and therefore will lead to quality improvement of crop production, agricultural soils and ecological state of the environment [3, 47].

It is known that most plant pathogens belong to gram-negative species and almost all bacteriocins synthesized by these bacteria are proteins [47, 51]. Gram-positive species dominate among microorganisms found in soil and rhizosphere of plants, as well as among saprophytic bacteria. For these bacteria, many peptide bacteriocins, especially of the first class (lantibiotics), have been identified and characterized [9, 22]. Instead, bacteriocins of phytopathogenic bacteria have been investigated selectively [2]. Information on bacteriocins synthesized by most of these microorganisms is missing. For some species, only initial studies were conducted, denoting the presence of certain substances with antimicrobial activity and their basic characteristics. Also little is known about the structure, killer activity, regulatory systems, and killer activity spectrum of the detected bacteriocins [20].

Pseudomonas syringae strains are characterized by high injuriousness and a high frequency of isolation (50-80\% - on leguminous plants and up to $90 \%$ - on cereal crop) among the plant pathogens. The inherent trait of these microorganisms is high resistance (90-100\%) to most commercial chemical and biological pesticide preparations $[45,54]$. Therefore, it is relevant to search new means for plant protection against diseases caused by these microorganisms $[50,55]$. So, in Lavermicocca et al. research [46] from Pseudomonas syringae pv. ciccaronei were isolated and purified bacteriocins, potentially containing three proteins with a molecular weight from 45 to $76 \mathrm{kDa}$. The authors showed that these bacteriocins inhibit the reproduction of Pseudomonas syringae subsp. savastanoi causative agent of the olive knot disease both in the laboratory and in the field experiments [51]. The results of the genome sequence of a phytopathogenic bacterium Pseudomonas syringae pv. syringae revealed the presence of S-type pyocins [56], also found in human opportunistic pathogen Pseudomonas aeruginosa $[11,57]$. These killer factors with a molecular weight of $65-80$ $\mathrm{kDa}$ belong to colicin-like bacteriocins $[6,38]$. S-type pyocins consist of two components: a large component with killer activity and small component (immunity protein) [11]. They mainly inhibit the activity of other pseudomonas species $[38,58]$. It was found that under plant treatment with bacteriocins, killer factors prevent the spread of phytopathogenic microorganisms by influencing their epiphytic phase [59]. Antimicrobial activity against a significant number of Pseudomonas species, in particular to a number of Pseudomonas syringae pathovars, is characterized for putidacins $P$. putida bacteriocins. So, for the rhizospheric isolate Pseudomonas sp. BW11M1 the production of lectin-like putidacins (LlpA) with a molecular weight of $30 \mathrm{kDa}$ was revealed. This bacteriocin contains sites that are similar to the mannosebinding domains of lectins from monocotyledonous plants [20]. Recently, two lectin-like bacteriocins with similar inhibitory spectrum of action were also identified in widely used biocontrol strain Pseudomonas fluorescens Pf-5 [60]. The biological properties of some pseudomonad strains, in particular $P$. fluorescens and $P$. putida, which are not only antagonistic to phytopathogenic microorganisms but also characterized by growthstimulating activity, have been described in the literature $[61,62]$. The advantage of these $P$. fluorescens and $P$. putida cultures is also the ability to induce the development of systemic resistance in plants. The given examples indicate the urgency of development of biopreparations based on fluorescent pseudomonad species; however, their number remains low [51,63].

Bacterial burn of fruit trees caused by phytopathogenic bacteria Erwinia amylovora is a particularly dangerous, quarantine disease [64]. It brings on necrotic lesions of Rosales plants and creates great difficulties leading to significant crop losses of fruit trees [3]. For biological control of bacterial burns of fruit trees Kearns and Mahanty proposed to use E. herbicola bacteriocins [65].

Also the influence of seracin $\mathrm{P}$ - high molecular weight bacteriocin of phage-tail type isolated from Serratia plymithicum - on the causative agent of this disease is investigated [20,64]. Another bacteriocin-producing strain Serratia entomophila is the basis of biopreparation (biopesticide) Invade, used against New Zealand larvae Costelytra zealandica [66]. Similar killer factors have also been found in Rhizobium strains. Quite 
possible, that tailocins described in earlier studies of Pseudomonas syringae also belong to this type [20]. It was shown that Pseudomonas aeruginosa bacteriocins are also characterized by high activity against phytopathogenic bacteria. Moreover, they affect not only $P$. syringae strains but also P. savastanoi $[50,55]$.

Other representatives of Erwinia genus and microorganisms currently reclassified into the new Pectobacterium genus also cause significant losses to the national economy. P. carotovorum and $P$. chrysanthemi should be especially noted as they cause maceration and necrosis of plant tissues, entailing lesions of potatoes, cereals and many other cultivated plants in temperate, tropical and subtropical latitudes [67]. F.I. Tovkach and his scientific school have made a significant contribution to the study of $P$. carotovorum bacteriocins. For example, it was shown that the lysogenic system of the phytopathogenic bacterium $P$. carotovorum is a unique model for research, since the simultaneous production of two bacteriocin types - macromolecular and colicinlike carotovoricins - is possible under the induction of this system $[16,68]$. A similar multiplicity of killer factor synthesis was observed only for a small number of bacterial species. It was also determined that killer particles were produced in different percentages depending on type of inducing factors [69]. And the secretion of carotovorcins has a wavelike character [70]. In F.I. Tovkach's study it was shown that $P$. carotovorum bacteriocins are capable of affecting a number of Enterobacteriaceae family microorganisms that can cause disease in animals and humans [16]. Pectobacteria, in turn, don't possess pathogenic properties against mammals, and substances produced by these bacteria are less toxic under parenteral dosing than similar substances of other producers.

Recently it was shown that Pectobacterium carotovorum (formerly known as Erwinia carotovora ssp. carotovora) produce small colicin and pyocin-like antimicrobial proteins with a molecular weight of about $55 \mathrm{kDa}$, designated as $\mathrm{S} 1$ carocins. This protein inhibits other strains of the same species, probably due to DNase activity [71].

Carotovoricin-producing strains can be also referred to means of bacterial plant diseases control. Thus, for treatment and spread limitation of Chinese cabbage soft rot caused by P. carotovorum subsp. carotovorum pathogenic strains, avirulent bacteriocin-producing mutant strains of the same species can be used [72].
Gram-negative phytopathogenic bacteria can also produce bacteriocins, which possess antibacterial activity by self-assembly into cytotoxic phage-like killer particles (high molecular weight bacteriocins). Carotovoricins produced by Pectobacterium carotovorum are the most studied representatives of this group [73]. It was shown that these bacteriocins are also characterized by lytic activity against closely related microorganisms [69]. Moreover, the killer spectrum of these bacteriocins is determined by the structure of tail fibres [74].

Tailocins have also been detected in Ralstonia solanacearum (previously Pseudomonas solanacearum). These bacteriocins inhibit growth of phytopathogenic microorganisms not only in laboratory experiments but also on plant objects in field conditions [20]. It was shown that plant immersion in a suspension of a bacteriocin-producing avirulent strain of these bacteria prevents the development of bacterial tobacco fading. Also tomatoes treatment by bacteriocin-producers reduces the percentage of their loss from withering. Similar activity was also observed for high molecular weight bacteriocins synthesized by Rhizobium lupini 16-3 that inhibits Pseudomonas syringae [20].

Several representatives of phytopathogenic microorganisms can produce protein bacteriocins, which are different from the antimicrobial agents described above. These bacteriocins are not sufficiently characterized to be referred to certain group or for classification, but they possess high activity against plant pathogens. Thus, heterodimeric bacteriocins called glycinecins were isolated from Xanthomonas campestris pv. glycines - the causative agent of soya bacterial pustules [3]. These substances are heterodimers of two polypeptides. Genetic determinants of this killer factor are localized in two separate genes glyA and glyB, which synthesize 39 and $14 \mathrm{kDa}$ subunits respectively [75]. Glycinesin does not have substantial similarity to sequences of other currently known protein bacteriocins and acts by increasing the permeability of target cell membranes [76]. The spectrum of these bacteriocins activity mainly includes other pathovars of $X$. campestris, and $X$. oryzae pv. oryzae, which causes bacterial burns in rice [75]. The results of other investigations revealed that glycinesin A is capable of affecting most phytopathogenic bacteria of Xanthomonas genus [3]. The plant treatment by nonpathogenic bacteriocin-producing $X$. campestris 
pv oryzae strains substantially reduced the spread and development of the most dangerous leaf form of bacterial burns, which provokes watery spots, stripes and yellowing of rice leaves $[3,77]$. Hert et al. showed in laboratory and field experiments that uncharacterized proteins production helped Xanthomonas perforans to inhibit tomato pathogen Xanthomonas euvesicatoria [78]. Colicin-like proteins were also found in the genomes of both sequenced strains Xanthomonas oryzae pv. oryzae and Xylella fastidiosa [20]. Oresnik et al. revealed that Rhizobium leguminosarum strains produced RTX-type toxins with molecular weight about $100 \mathrm{kDa}$. These proteins provide a competitive advantage of producing strains against closely related phytopathogenic microorganisms in the process of plant nodules occupancy [79].

The research of phytopathogenic microorganisms' bacteriocins is obviously important. The agriculture needs environmentally safe and effective methods for plant disease control [60]. Under such study, new narrow-spectrum antimicrobial compounds can be revealed, capable of satisfying these requirements [20, 25]. If economically substantiated production is created or approaches to their synthesis are developed, bacteriocins can be used in the semipurified state. On the other hand, killer factors must be obtained from avirulent producing strains. After all, there is an alternative to create bacteriocin-producing transgenic crops $[7,80]$. Thus, several approaches for bacteriocin application in crop production are considered, which can provide the creation of new means for plant diseases control [2]. The study of bacteriocins of marine microorganisms is at similar stage. However, the prospects for their use have other peculiarities.

\section{Bacteriocins of marine microorganisms}

According to the FAO report, the average consumption of aquaculture products comparatively to the total fish consumption per person increased from $14 \%$ in 1986 to $47 \%$ in 2006 [19]. It is expected that this index will grow up to $50 \%$ in following years [81]. However, the development and intensification of water industry can lead not only to a rise of the density of aquaculture population, but also to an increase in the infectious lesion of its representatives by pathogenic microorganisms [82]. Significant economic losses in fish production are due to diseases provoked by a limited range of microorganisms. Vibrio strains are one of the most widespread pathogens that cause high mortality of fish larvae culture [83]. Climate change is also important, as many microorganisms at higher temperature have higher virulence and transmission [84]. At the same time, the preventive use of antibiotics is harmful [85]. Vaccines, antimicrobials and probiotic cultures were proposed for pathogen growth inhibition [82]. Bacteriocinogenic strains are considered as a great alternative to antibiotics, since bacteriocins can substitute antibiotics and their producing bacteria-potential probiotics [7, 22].

Living organisms, present in the upper layer of the sea surface, are capable for production of a considerable number of antibacterial compounds [86]. Many papers described antimicrobial substances synthesized by marine microorganisms isolated from sponges, corals, algae and shellfish $[87,88]$. However, only a few studies examined the ability of bacteria associated with marine animals to synthesize bacteriocins [19]. There are several cases when substances previously considered being produced by higher organisms were synthesized by microorganisms. An example of such substance is patellamide - a peptide with bioactive properties, synthesized by Prochloron didemni [89]. The microorganisms associated with marine animals include bacteria of Vibrio, Pseudoalteromonas, Aeromonas, Alteromonas genera, and also Cytophaga-FlavobacteriumBacteroides group [87]. There is a set of reports concerning antibacterial peptides or proteins which were synthesized by marine bacteria and identified by combining sequencing methods and detection of structural organization. Wilson et al. isolated 8 strains of marine bacteria able to produce antibacterial substances from a wide variety of marine invertebrates (oysters, shellfish, sponges, tunics, sea urchins, algae) [87]. The loss of activity of these substances after proteolytic cleavage suggests their protein nature [19].

However the application of purified bacteriocins in aquaculture is insufficiently profitable. Selection of associated with marine animals bacteriocinogenic and nonpathogenic bacteria for their use as probiotics is more advantageous [19]. The definition of term "probiotic" was formulated by Fuller in 1989, then partially modified by Salminen in 1999, and now WHO interprets that "Probiotics are live microorganisms, which in adequate quantities help to improve the health of the host" [90]. It should be noted that pathogenic bacteria in the aquatic environment reproduce independently of the host. They can reach a 
high concentration in water and become able to permanently affect the intestinal microbiota of aquatic organisms through their ingestion [91]. Therefore, probiotic strains for aquaculture must be significantly different from those used in animal husbandry or medicine, since they have to influence not only host, but also environment [92].

In view of the above, a strategy for the selection of bacteriocin-producing strains for aquaculture was developed. The first and most important step is the in vitro screening of bacteria associated with aquatic organisms for the presence of antagonistic activity against pathogens [93]. Probiotic bacteria must be isolated from microbiota of aquatic vertebrates or invertebrates. It will improve their establishment and allow maintain the productivity under possible difference of temperature and salinity from optimal parameters for these microorganisms [94]. The second stage of selection involves determination of nature of inhibitory substance, its mechanism of action and genetic aspects of localization. The third step is the test of in vivo safety of bacteriocin use for both the host and the environment. Also at this stage the profitability of selected substances application under appropriate growing conditions is evaluated [93].

It is important that dominant members of the normal microbiota of gastrointestinal tract of endothermic animals in the early stages of their life are gram-positive bacteria. The gastrointestinal microbiota of healthy fish usually contains lactic acid bacteria belonging to Streptococcus, Lactobacillus, Carnobacterium, Leuconostoc genera [19]. Most of the probiotics used in aquaculture are widely researched and belong to lactic acid bacteria and members of the genus Bacillus [95-97]. Among gram-negative bacteria, the representatives of Aeromonas, Pseudomonas, Pseudoalteromonas, Roseobacter and Vibrio genera have considerable potential [93, 98].

Bacteriocin-like substances of Vibrio sp. Bacteria of Vibrio genus are widespread in the marine environment and, in most cases, isolated from fish and shellfish [99]. Some types of vibrios can cause diseases of marine organisms and humans, while others are non-pathogenic. For some Vibrio strains the ability to secrete bacteriocin-like inhibitory substances (in abbreviated form - BLIS) was described.

Zai et al. [100] isolated and identified $50 \mathrm{Vib}$ rio strains from gills and viscera of healthy and infected catfish. For these strains BLIS was found out and called vibriocin AVP10 [19].

Fresh and frozen seafood was analyzed by Carraturo et al. [101]. These researchers isolated 3 non-pathogenic for human Vibrio species ( $V$. mediterranei $1, V$. mediterranei 4 and $V$. fluvialis), which on a dense agar medium exhibited antagonistic activity against pathogenic strains of the same genus - V. parahaemolyticus and $V$. mediterranei. For BLIS of $V$. mediterranei 1, the step-by-step partial purification was described. The albuminous nature of the isolated substances was confirmed by enzymatic cleavage by proteinase $\mathrm{K}$. Carraturo et al. [101] used gel chromatography to purified the fraction with antimicrobial activity. Determined by SDS-PAGE the molecular weight of purified BLIS was $63-65 \mathrm{kDa}$ and corresponded to a mixture of unrelated polypeptides, among which bacteriocins were detected [19].

$V$. harveyi strains are pathogenic for many invertebrates and vertebrates marine animals [102, 103]. McCall and Sizemore [19] firstly informed of bacteriocin production by strain Beneckea harveyi ( $V$. harveyi), which was designated as harveyicin SY. This bacteriocin was characterized by a molecular weight of about $24 \mathrm{kDa}$ and caused lysis of two strains $V$. harveyi KN96 and BBP8. Harveicin proved to be sensitive to proteolytic enzymes, and its genetic determinants were obviously plasmid-associated [19]. During screening of $V$. harveyi culture collection, Prasad et al. [102] discovered ability of strain VIB 571 to produce BLIS. This culture was pathogenic for rainbow trout (Oncorhynchus mykiss) and Atlantic salmon (Salmo salar) [103]. Inter-strain and inter-species inhibition due to bacteriocin-like inhibitors of $V$. harveyi VIB 571 was detected against 4 isolates of the same species and also against $V$. fischeri, $V$. gazogenes, and $V$. parahaemolyticus. The impure BLIS was obtained by ammonium sulfate precipitation from 72-hour culture previously purified from cells. It was inactivated by lipase, proteinase $\mathrm{K}$, pepsin, trypsin, pronase $\mathrm{E}$ and SDS. Incubation of bacteriocins for $10 \mathrm{~min}$ at $60^{\circ} \mathrm{C}$ and above caused loss of their activity. On the other hand, the change in $\mathrm{pH}$ did not affect the antibacterial activity. By means of ion exchange chromatography, gel filtration, SDS-PAGE and two-dimensional gel electrophoresis it was detected one major peak represented by a protein with a pI of about $\sim 5.4$ and molecular weight of about $32 \mathrm{kDa}$. The sequence of the N-terminus of this protein was established: D-E-Y-I-S-X-N-K-X-S-S-A-D-I, where at position 
' $\mathrm{X}$ ' there could be either cysteine or a modified amino acid residue [19].

Shehane and Sizemore obtained other vibriocins [104]. The purpose of these researches was to identify bacteriocins, active against $V$. vulnificus, isolated from seafood. They tested antimicrobial activity of plasmid-containing strains sampled from the mouth near the port of Wilmington (North Carolina, USA). Strains whose antimicrobial activity was due to lytic bacteriophages or low molecular weight nonspecific molecules were rejected immediately. As a result, three producers of bacteriocins were revealed among $V$. vulnificus and their inhibition spectrum was determined. Thus, the first selected strain IW1 inhibited a small number of $V$. vulnificus cultures. The second isolate BC1 - several strains of $V$. vulnificus, as well as $V$. cholerae and $V$. parahaemolyticus. Instead, a third producer $\mathrm{BC} 2$ excreted substances that inhibited the growth of all used strains of Vibrio spp, Plesiomonas shigelloides, and E. coli. It was found that the loss of bacteriocinogenic plasmid by these isolates caused the loss of inhibitory activity. By means of gel chromatography, the molecular weight of bacteriocins from strain IW1 was found to be $9.0 \mathrm{kDa}$, for strain $\mathrm{BC} 1$ it was $7.5 \mathrm{kDa}$, and for $\mathrm{BC} 2-1.35 \mathrm{kDa}$. It should be noted that isolated bacteriocins differed significantly in the sensitivity to temperature. Thus, the substances of strain IW1 were thermolabile. The bacteriocins of $\mathrm{BC} 1$ isolate were characterized by moderate stability as they lost activity only after treatment with extreme temperatures. Instead, $V$. vulnificus BC2 substances were highly stable and retained activity after autoclaving, freezing, and exposure to extreme $\mathrm{pH}$ values [104]. In consideration of the broad activity spectrum of obtained bacteriocins, the authors have suggested that these substances can be used as control agents for $V$. vulnificus to remove it from seafood [19].

Vibrio sp. NM 10 was isolated from Leiognathus nuchalis fish caught in coastal areas near Enosima Island (Kanagawa, Japan). This strain was characterized by high activity against Pasteurella piscicida $\mathrm{K}$-III, and was also able to inhibit growth of E. coli IAM 1264, V. vulnificus RIMD 2219009 and Enterococcus seriolicida YT-3 [105]. Antibacterial substance synthesized by Vibrio sp. NM 10 proved to be a protein thermolabile compound with a molecular weight below $5 \mathrm{kDa}$, which indicates its belonging to bacteriocins or bacteriocin-like substances $[19,105]$.
Bacteriocin-like substances of Aeromonas sp. The production of bacteriocin-like substances in Aeromonas hydrophila was studied by Moro et al. and Messi et al. [106]. All investigated $A$. hydrophila strains possessed the inhibitory activity against several Staphylococcus aureus strains. Messi et al. revealed an additional inhibitory effect of BLIS against Listeria sp, Streptococcus agalactiae and Lactobacillus sp. However, the obtained substances did not influence on all tested gram-negative strains, including closely related species - Aeromonas sobria ATCC 43979 and A. caviae ATCC 13137. It should be noted that such an inhibitory spectrum is incompatible with the determination of bacteriocins, which allows belonging of the test substances to another class of antimicrobial compounds [19].

Bacteriocin-like substances of Pseudoalteromonas sp. In Longeon et al. [107] paper the bacteria isolated from different ecosystems on the UK coast were discussed. The main focus of this work was on the study of nature and biological properties of antimicrobial substances of Pseudoalteromonas X-153. This priority was caused by the high antagonistic activity of this strain against a wide range of microorganisms. As a result of conducted research the main active substance was obtained and purified - protein P-153. This protein possessed antibacterial activity and, according to gel chromatography data, had molecular weight of $87 \mathrm{kDa}$. Protein P-153 was active against both Gracilicutes (ichthyopathogenic Vibrio) and Firmicutes (Staphylococcus epidermidis, Propionibacterium acnes and P. granulosum) bacteria [107]. However, it should be noted that the described spectrum of activity is too broad and not compatible with the determination of bacteriocins [19].

Highly active bacteriocins have been isolated from marine strain BS107 identified as Roseobacter [108]. However, it was found that these microorganisms cannot be used for treatment, when the pathogen is present in a concentration sufficient to cause an outbreak of the disease. The authors demonstrated that under simultaneous inoculation of BS107 (even in concentration of $10^{6} \mathrm{CFU} / \mathrm{ml}$ ) and Vibrio pectenicida A496 (in concentration of $10^{4} \mathrm{CFU} / \mathrm{ml}$ ), the strain BS107 did not possess any probiotic activity. Therefore, it is important to note that bacteriocin-producing probiotics should be used for preventive purposes [36, 108]. 
Thus, killer factors of marine microorganisms are powerful antimicrobials, but their use is possible only due to application of producing strains [92, 95]. Getting into the environment, microorganisms, like most other bacteria, start to form a biofilm $[109,110]$. In its composition the intensity of bacteriocin production and effectiveness of their action against competitive strains may differ significantly from that described for bacteria in planktonic form $[111,112]$. We have shown that the synthesis of killer factors in the biofilm form depend on the environment and, apparently, the temperature of microorganism cultivation $[113,114]$. Studies conducted on the classic model of Pseudomonas aeruginosa indicate that the process of biofilm formation goes through a series of stages characterized by certain structural features [115-117]. In this case, the transition to the biofilm form almost immediately causes the bacterial resistance to the action of antimicrobial substances [118]. The mentioned features should be taken into consideration and bacteriocins and their producing strains $[119,120]$ must be tested before their application to the environment.

Thus, the need for specific antimicrobial agents that can be used in crop production and aquaculture, and significant potential of bacteriocins promoted the intensive increase of work quantity in this area over the past decades. However, it should be noted that most of the studies are still at the initial stages. There is a hope that these investigations will be continued and find practical application in the form of biopreparations.

1. Riley MA, Chavan M. Bacteriocins: ecology and evolution. Berlin; Heidelberg: Springer-Verlag; 2007. $154 \mathrm{p}$.

2. Montesinos E. Antimicrobial peptides and plant disease control. FEMS Microbiol Lett. 2007; 270:1-11.

3. Gillor O, Nigro LM, Riley MA. Genetically engineered bacteriocins and their potential as the next generation of antimicrobials. Curr Pharm Des. 2005; 11(8):1067-1075.

4. Balko AB. [Characteristic, properties, prospect of application of bacteriocins]. Mikrobiol Z. 2012; 74(6):99-106. Russian.

5. Yang S-C, Lin C-H, Sung CT, Fang J-Y. Antibacterial activities of bacteriocins: application in foods and pharmaceuticals. Front Microbiol. 2014; 5:241.

\section{БАКТЕРІОЦИНИ ДЕЯКИХ ГРУП ГРАМНЕГАТИВНИХ БАКТЕРІЙ}

\section{О.І. Балко, О.Б. Балко, Л.В. Авдєєва}

Інститут мікробіології і вірусології ім. Д.К. Заболотного НАН України, вул. Академіка Заболотного, 154, Київ, 03143, Украӥна

\section{Резюме}

Проаналізовано результати досліджень бактеріоцинів грамнегативних бактерій - кілерних факторів, які характеризуються потужною антимікробною активністю, вузько направленим спектром дії і безпечністю для макроорганізму. Бактеріоцини, особливо грамнегативних бактерій, досліджені вкрай неоднаково i, в більшості випадків, недостатньо, а наявна інформація не систематизована. В наведеній роботі зроблено акцент на бактеріоцинах, активних щодо фітопатогенних бактерій, які можуть бути використані в рослинництві як самостійні засоби впливу, а також на кілерних факторах морських мікроорганізмів, застосування яких у водному господарстві припустиме лише разом із їх мікроорганізмами-продуцентами.

Ключові слова: бактеріоцини, фітопатогенні бактерії, рослинництво, морські мікроорганізми, водне господарство.

6. Ghequire MGK, De Mot R. Ribosomally encoded antibacterial proteins and peptides from Pseudomonas. FEMS Microbiol Rev. 2014; 38:3852338568.

7. Gillor O, Etzion A, Riley MA. The dual role of bacteriocins as anti- and probiotics. Appl Microbiol Biotechnol. 2008; 81:591-606.

8. Braun V, Pilsl H, Gross P. Colicins: structures, modes of action, transfer through membranes and evolution. Arch Microbiol. 1994; 161(3):199206.

9. Riley MA. Molecular mechanisms of bacteriocin evolution. Annu Rev Genet. 1998; 32:255-278.

10. Riley MA, Wertz JE. Bacteriocin diversity: ecological and evolutionary perspectives. Biochimie. 2002; 84(5):357-364. 
11. Michel-Briand Y, Baysse C. The pyocins of Pseudomonas aeruginosa. Biochimie. 2002; 84(5):499-510.

12. Nakayama K, Takashima K, Ishihara H, et. al. The R-type pyocin of Pseudomonas aeruginosa is related to $\mathrm{P} 2$ phage, and the F-type is related to lambda phage. Mol Microbiol. 2000; 38(2):213-231.

13. Balko OI, Balko AB, Avdeeva LV. [Biofilm forming capacity and bacteriocynogenity in Pseudomonas aeruginosa]. In: Mokienko AV, Pushkina VA, Gozhenko AI, editors. Biofilms of hospital ecosystems: condition, problems and modern approaches to its solve. Odessa: TOV VNP "Interservise"; 2014. p. 247-311. Russian.

14. Balko OB. Low molecular weight Pseudomonas aeruginosa bacteriocins. Mikrobiol Z. 2019; 81(6):97-109.

15. Balko AB, Avdeeva LV. [Screening of producers of bacteriocin-like substances active against Pseudomonas aeruginosa]. Mikrobiol Z. 2012; 74(2):8-13. Russian.

16. Tovkach FI. Biological properties and classification of Erwinia carotovora bacteriocins. Microbiology. 1998; (67)6:636-642.

17. Tovkach FI, Maksimenko LO, Balko OB. [The multiplicity of bacteriocins of Erwinia carotovora]. Visn Nation Agroecol Univ. 2005; 2:163168. Ukrainian.

18. Maksimenko LO, Balko OI, Balko OB. Pectobacterium carotovorum subsp. carotovorum low-molecular-weight carotovoricins. Microbiology \& Biotechnology. 2017; 3(39):75-83.

19. Desriac F, Defer D, Bourgougnon N, et al. Bacteriocin as weapons in the marine animal-associated bacteria warfare: inventory and potential applications as an aquaculture probiotic. Marine Drugs. 2010; 8(4):1153-1177.

20. Holtsmark I, Eijsink VGH, Brurberg MB. Bacteriocins from plant pathogenic bacteria. FEMS Microbiol Lett. 2008; 280:1-7.

21. Dicks LMT, Dreyer L, Smith C, van Staden AD. A review: the fate of bacteriocins in the human gastro-intestinal tract: do they cross the gutblood barrier? Front Microbiol. 2018; 9:2297.
22. Joerger RD. Alternatives to antibiotics: Bacteriocins, antimicrobial peptides and bacteriophages. Poultry Science. 2003; 82:640-647.

23. Silva CCG, Silva SPM, Ribeiro SC. Application of Bacteriocins and Protective Cultures in Dairy Food Preservation. Front Microbiol. 2018; 9:594.

24. Hols P, Ledesma-García L, Gabant P, Mignolet J. Mobilization of Microbiota Commensals and Their Bacteriocins for Therapeutics. Trends Microbiol. 2019; 27(8):690-702.

25. Hahn-Löbmann S, Stephan A, Schulz S, Schneider T, Shaverskyi A, et. al. Colicins and salmocins-New classes of plant-made non-antibiotic food antibacterials. Front. Plant Sci. 2019; $10: 437$.

26. Mathur H, Field D, Rea MC, et. al. Bacteriocin-Antimicrobial Synergy: A Medical and Food Perspective. Front Microbiol. 2017; 8:1205.

27. Tovkach FI., Balko AB. [Structural and morphological organization of basal plates of deficient bacteriophages of Erwinia carotovora]. Visn Taras Shevchenko Nation Univer Kyiv. 2005; 44:38-39. Ukrainian.

28. Guliy OI, Bunin VD, Balko AB, et al. Effect of sulfonamides on the electrophysical properties of bacterial cells. Anti-Infective Agents. 2014; 12(2):191-197.

29. Guliy OI, Zaitsev BD, Kuznetsova IE, et al. Application of the method of electro-acoustical analysis for the detection of bacteriophages in a liquid phase. Biophysics. 2016; 61(1):52-58.

30. Guliy OI, Bunin VD, Larionova OS, et al. [Change of electrophysical properties of Escherichia coli cells due to levomycetin and tetracycline action]. Antibiotics and Chemotherapy. 2016; 61(1-2):3-8. Russian.

31. Krylov VN. [Phage therapy in terms of bacteriophage genetics: Hopes, perspectives, safety, limitations]. Genetika. 2001; 37(7):869-887. Russian.

32. Lopetuso LR, Giorgio ME, Saviano A, Scaldaferri F, Gasbarrini A, Cammarota G. Bacteriocins and Bacteriophages: Therapeutic Weapons for Gastrointestinal Diseases? Int J Mol Sci. 2019; 20(1). pii:E183. 
33. Meade E, Slattery MA, Garvey M. Bacteriocins, Potent Antimicrobial Peptides and the Fight against Multi Drug Resistant Species: Resistance Is Futile? Antibiotics (Basel). 2020; 9(1). pii:E32.

34. Ghodhbane H, Elaidi S, Sabatier JM, Achour S, Benhmida J, Regaya I. Bacteriocins Active Against Multi-Resistant Gram-Negative Bacteria Implicated in Nosocomial Infections. Infect Disord Drug Targets. 2015; 15(1):2-12.

35. Ahmad V, Khan MS, Jamal QMS, Alzohairy MA, Al Karaawi MA, Siddiqui MU. Antimicrobial potential of bacteriocins: in therapy, agriculture and food preservation. Int J Antimicrob Agents. 2017; 49(1):1-11.

36. Rather IA, Galope R, Bajpai VK, Lim J, Paek WK, Park Y-H. Diversity of Marine Bacteria and Their Bacteriocins: Applications in Aquaculture. Rev Fish Sci Aquacult. 2017; 25(4):257269.

37. Balko OB. [Structural and functional organization of carotovoricins and their role in bacterial antagonism]: The candidate degree thesis by speciality 03.00.06 Kyiv, 2007. 20 p. Ukrainian.

38. Sano Y, Matsui H, Kobayashi M, Kageyama M. Molecular structures and functions of pyocins S1 and S2 in Pseudomonas aeruginosa. J Bacteriol. 1993; 175(10):2907-2916.

39. Duquesne S, Destoumieux-Garzon D, Peduzzi J, Rebuffat S. Microcins, gene-encoded antibacterial peptides from enterobacteria. Nat Prod Rep. 2007; 24:708-734.

40. Duquesne S, Petit V, Peduzzi J, Rebuffat S. Structural and functional diversity of microcins, gene-encoded antibacterial peptides from enterobacteria. J Mol Microb Biotech. 2007; 13:200209.

41. Tan S, Moore G, Nodwell J. Put a bow on it: Knotted antibiotics take center stage. Antibiotics. 2019; 8(3):117.

42. Pons AM, Lanneluc I, Cottenceau G, Sable S. New developments in non-post translationally modified microcins. Biochimie. 2002; 84(6):531-537.

43. Parks WM, Bottrill AR, Pierrat OA, et. al. The action of the bacterial toxin, microcin B17, on DNA gyrase. Biochimie. 2007; 89:500-507.
44. Balko OI, Balko OB, Avdeeva LV. Thermoactivation of Pseudomonas aeruginosa pyocins. Mikrobiol Z. 2019; 81(5): 85-97.

45. Gvosdyak RI, Pasichnik LA, Yakovleva LM, Moroz SM, Litvinchuk OO, et. al. [Phytopathogenic bacteria. Bacterial diseases of plants]. Kiev: SPE Interservice; 2011. 444 p. Ukrainian.

46. Lavermicocca P, Lonigro SL, Valerio F, et. al. Reduction of olive knot disease by a bacteriocin from Pseudomonas syringae pv. ciccaronei. Appl Environ Microbiol. 2002; 68(3):1403-1407.

47. McManus PS, Stockwell VO, Sundin GW, Jones AL. Antibiotic use in plant agriculture. Annu Rev Phytopathol. 2002; 40:443-465.

48. Subramanian S, Smith DL. Bacteriocins from the rhizosphere microbiome - from an agriculture perspective. Front Plant Sci. 2015; 6:909.

49. Balko OB, Tovkach FI. [Endonuclease activity associated with the bacteriocin particles of Erwinia carotovora]. Nauk Visn Chernivetsk Univer. 2006; 297:132 - 136. Ukrainian.

50. Pat. 120295 UA, МПК A01N 25/00, C12R 1/38, C12R 1/385, C12N 1/20. [A method of plant protection from bacterial disease agent Pseudomonas syringae]. Balko OB, Balko OI, Zelena LB, Pasichnik LA, Avdeeva LV. Publ. 11.11.2019, Bull. № 21. Ukrainian.

51. Parret AHA, Schoofs G, Proost P, de Mot R. Plant lectin-like bacteriocin from a rhizosphere-colonizing Pseudomonas isolate. J Bacteriol. 2003; 185(3):897-908.

52. Lenski RE, Riley MA. Chemical warfare from an ecological perspective. PNAS USA. 2002; 99:556-558.

53. Ghequire MG, Dillen Y, Lambrichts I, Proost P, Wattiez R, De Mot R. Different ancestries of R tailocins in rhizospheric Pseudomonas isolates. Genome Biol Evol. 2015; 7(10):2810-2828.

54. Rooney WM, Grinter RW, Correia A, Parkhill J, Walker DC, Milner JJ. Engineering bacteriocin-mediated resistance against the plant pathogen Pseudomonas syringae. Plant Biotechnol J. 2019; doi: 10.1111/pbi.13294.

55. Balko OI, Yaroshenko LV, Balko OB, Pasichnyk LA, Avdeeva LV. [Pseudomonas aeruginosa bacteriocin activity against Pseudomonas syringae phytopathogenic strains]. Microbiology and 
biotechnology. 2017; 2:51-60. Ukrainian.

56. Feil H, Feil WS, Chain P, et al. Comparison of the complete genome sequences of Pseudomonas syringae pv. syringae $\mathrm{B} 728 \mathrm{a}$ and $\mathrm{pv}$. tomato DC3000. PNAS USA. 2005; 102:11064-11069.

57. Balko AB, Vidasov VV, Avdeeva LV. [Optimization of Pseudomonas aeruginosa bacteriocin induction]. Microbiol Z. 2013;75(1):79-85. Russian.

58. Paškevičius ŠS, Starkevič U, Misiūnas A, Vitkauskienė A, Gleba Y, Ražanskienė A. Plant-expressed pyocins for control of Pseudomonas aeruginosa. PLoS One. 2017; 12(10):e0185782.

59. Kairu GM. Biochemical and pathogenic differences between Kenyan and Brazilian isolates of Pseudomonas syringae pv. garcae. Plant Pathol. 1997; 46:239-246.

60. Parret AHA, Temmerman K, De Mot R. Novel lectin-like bacteriocins of biocontrol strain $\mathrm{Pseu}$ domonas fluorescens Pf-5. Appl Environ Microbiol. 2005; 71:5197-5207.

61. Bloemberg G, Lugtenberg B. Molecular basis of plant growth promotion and biocontrol by rhizobacteria. Curr Opin Plant Biol. 2001; 4:343-350.

62. Abhilash PC, Dubey RK, Tripathi V, Gupta VK, Singh HB. Plant Growth-Promoting Microorganisms for Environmental Sustainability. Trends Biotechnol. 2016; 34(11):847-850.

63. Príncipe A, Fernandez M, Torasso M, Godino A, Fischer S. Effectiveness of tailocins produced by Pseudomonas fluorescens SF4c in controlling the bacterial-spot disease in tomatoes caused by Xanthomonas vesicatoria. Microbiol Res. 2018; 212-213:94-102.

64. Jabrane A, Sabri A, Compre P, et. al. Characterization of serracin $\mathrm{P}$, a phage-tail-like bacteriocin, and its activity against Erwinia amylovora, the fire blight pathogen. Appl Environ Microbiol. 2002; 68(11):5704-5710.

65. Kearns LP, Mahanty HK. Antibiotic production by Erwinia herbicola Eh1087: its role in inhibition of Erwinia amylovora and partial characterization of antibiotic biosynthesis genes. Appl Environ Microbiol. 1998; 64(5):1837-1844.

66. Hurst MRH, Glare TR, Jackson TA. Cloning Serratia entomophila antifeeding genes - a putative defective prophage active against the grass grub Costelytra zealandica. J Bacteriol. 2004; 186(15):5116-5128.

67. Toth IK, Bell KS, Holeva MC, Birch PRJ. Soft rot erwiniae: from genes to genomes. Mol Plant Pathol. 2003; 4(1):17-30.

68. Tovkach FI. [Relation between macromolecular carotovoricin lysing activity and bacteriocinsensitivity in E. carotovora]. Microbiology. 1998; 67(6):775-781. Russian.

69. Tovkach FI. [Defective lysogeny in Erwinia carotovora]. Microbiology. 2002; 71(3):359-367. Russian.

70. Tovkach FI, Mukvich NS, Balko AB. [Peculiarities of lysogenic induction of bacteriocins in thymine mutants of Erwinia carotovora]. Mikrobiol Z. 2006; 68(3):33-46. Russian.

71. Chuang DY, Chien YC, Wu HP. Cloning and expression of the Erwinia carotovora subsp. carotovora gene encoding the low-molecular-weight bacteriocin, carocin S1. J Bacteriol. 2007; 189:620-626.

72. Vanneste JL, Cornish DA, Yu J, Voyle MD. A microcin produced by a strain of Erwinia herbicola is involved in biological control of fire blight and soft rot caused by Erwinia sp. XXV International Horticultural Congress. Acta Hort. (ISHS) 513. 1998. p. 39-46.

73. Shyntum DY, Nkomo NP, Shingange NL, Gricia AR, Bellieny-Rabelo D, Moleleki LN. The Impact of Type VI Secretion System, Bacteriocins and Antibiotics on Bacterial Competition of Pectobacterium carotovorum subsp. brasiliense and the Regulation of Carbapenem Biosynthesis by Iron and the Ferric-Uptake Regulator. Front Microbiol. 2019; 10:2379-2403.

74. Nguyen HA, Tomita T, Hirota M, et. al. DNA inversion in the tail fiber gene alters the host range specificity of carotovoricin Er, a phage-tail-like bacteriocin of phytopathogenic Erwinia carotovora subsp. carotovora. Er J Bacteriol. 2001; 183:6274-6281.

75. Heu S, Oh J, Kang Y, et al. Gly gene cloning and expression and purification of glycinecin A, a bacteriocin produced by Xanthomonas campestris pv. glycines 8ra. Appl Environ Microbiol. 2001; 67:4105-4110. 
76. Pham HT, Riu KZ, Jang KM, et. al. Bactericidal activity of glycinecin A, a bacteriocin derived from Xanthomonas campestris pv. glycines, on phytopathogenic Xanthomonas campestris pv. vesicatoria cells. Appl Environ Microbiol. 2004; 70:4486-4490.

77. Sakthivel N, Mew TW. Efficacy of bacteriocinogenic strains of Xanthomonas oryzae pv oryzae on the incidence of bacterial-blight disease of rice (Oryza-sativa 1). Can J Microbiol. 1991; 37:764-768.

78. Hert AP, Roberts PD, Momol MT, et al. Relative importance of bacteriocin-like genes in antagonism of Xanthomonas perforans tomato race 3 to Xanthomonas euvesicatoria tomato race 1 strains 259. Appl Environ Microbiol. 2005; 71:35813588.

79. Oresnik IJ, Twelker S, Hynes MF. Cloning and characterization of a Rhizobium leguminosarum gene encoding a bacteriocin with similarities to RTX toxins. Appl Environ Microbiol. 1999; 65: 2833-2840.

80. Stephan A, Hahn-Löbmann S, Rosche F, et al. Simple purification of Nicotiana benthamiana-produced recombinant colicins: high-yield recovery of purified proteins with minimum alkaloid content supports the suitability of the host for manufacturing food additives. Int J Mol Sci. 2017; 19(1):E95.

81. FAO. Aquaculture topics and activities. Aquaculture. In: FAO Fisheries and Aquaculture Department [online]. Rome. Updated 14 September 2015.

82. Kurath G. Biotechnology and DNA vaccines for aquatic animals. REV SCI TECH OIE. 2008; 27:175-196.

83. Austin B, Zhang XH. Vibrio harveyi: a significant pathogen of marine vertebrates and invertebrates. Lett Appl Microbiol. 2006; 43:119-124.

84. Marcogliese D. The impact of climate change on the parasites and infectious diseases of aquatic animals. REV SCI TECH OIE. 2008; 27:467484.

85. Zhou Q, Li K, Jun X, Bo L. Role and functions of beneficial microorganisms in sustainable aquaculture. Bioresour Technol. 2009; 100:37803786.
86. Prakashwadekar B, Dharmadhikari SM. Screening of marine microorganisms as probiotics for production of bacteriocin. Intern J Develop Res. 2016; 6(10):9734-9738.

87. Wilson GS, Raftos DA, Corrigan SL, Nair SV. Diversity and antimicrobial activities of surface-attached marine bacteria from Sydney Harbour, Australia. Microbiol Res. 2010; 165(4):300-311.

88. Feliatra F, Muchlisin ZA, Teruna HY, Utamy WR, Nursyirwani N, Dahliaty A. Potential of bacteriocins produced by probiotic bacteria isolated from tiger shrimp and prawns as antibacterial to Vibrio, Pseudomonas, and Aeromonas species on fish. F1000Res. 2018; 7:415-434.

89. Schmidt EW, Nelson JT, Rasko DA, et. al. Patellamide $\mathrm{A}$ and $\mathrm{C}$ biosynthesis by a microcin-like pathway in Prochloron didemni, the cyanobacterial symbiont of Lissoclinum patella. Proc Natl Acad Sci. USA. 2005; 102(20):7315-7320.

90. Reid G, Sanders ME, Gaskins HR, et. al. New Scientific Paradigms for Probiotics and Prebiotics. J Clin Gastroenterol. 2003; 37:105-118.

91. Jorquera MA, Silva FR, Riquelme CE. Bacteria in the culture of the scallop Argopecten purpuratus (Lamarck, 1819). Aquaculture Int. 2001; 9:285-303.

92. Verschuere L, Rombaut G, Sorgeloos P, Verstraete W. Probiotic bacteria as biological control agents in aquaculture. Microbiol Mol Biol Rev. 2000; 64:655-671.

93. Sahu M, Swarnakumar N, Sivakumar K, et. al. Probiotics in aquaculture: importance and future perspectives. Indian J Microbiol. 2008; 48:299308.

94. Das S, Ward L, Burke C. Prospects of using marine actinobacteria as probiotics in aquaculture. Appl Microbiol Biotechnol. 2008; 81:419-429.

95. Wang Y-B, Li J-R, Lin J. Probiotics in aquaculture: Challenges and outlook. Aquaculture. 2008; 281:1-4.

96. Said LB, Gaudreau H, Dallaire L, Tessier M, Fliss I. Bioprotective Culture: A New Generation of Food Additives for the Preservation of Food Quality and Safety. Industr Biotechnol. 2019; 15(3):138-147.

97. Lim KB, Balolong MP, Kim SH, Oh JK, Lee JY, Kang DK. Isolation and Characterization 
of a Broad Spectrum Bacteriocin from Bacillus amyloliquefaciens RX7. Biomed Res Int. 2016; 2016:8521476. doi: 10.1155/2016/8521476.

98. Ahmad A, Hamid R, Dada AC, Usup G. Pseudomonas putida strain isolated from shark skin: A potential source of bacteriocin. Probiotics Antimicrob Proteins. 2013; 5(3):165-175.

99. Morris JJÂG. Cholera and Other Types of Vibriosis: A Story of Human Pandemics and Oysters on the Half Shell. Clin Infect Dis. 2003; 37:272280.

100. Zai AS, Ahmad S, Rasool SA. Bacteriocin production by indigenous marine catfish associated Vibrio spp. Pak J Pharm Sci. 2009; 22:162-167.

101. Carraturo A, Raieta K, Ottaviani D, Russo GL. Inhibition of Vibrio parahaemolyticus by a bacteriocin-like inhibitory substance (BLIS) produced by Vibrio mediterranei 1. J Appl Microbiol. 2006; 101:234-241.

102. Prasad S, Morris PC, Hansen R, et. al. A novel bacteriocin-like substance (BLIS) from a pathogenic strain of Vibrio harveyi. Microbiology. 2005; 151:3051-3058.

103. Zhang X-H, Austin B. Pathogenicity of Vibrio harveyi to salmonids. J Fish Dis. 2000; 23:93102.

104. Shehane SD, Sizemore RK. Isolation and preliminary characterization of bacteriocins produced by Vibrio vulnificus. J Appl Microbiol. 2002; 92:322-328.

105. Sugita H, Matsuo N, Hirose Y, et. al. Vibrio sp. strain NM 10, isolated from the intestine of a Japanese coastal fish, has an inhibitory effect against Pasteurella piscicida. Appl Environ Microbiol.1997; 63:4986-4989.

106. Messi P, Guerrieri E, Bondi M. Bacteriocin-like substance (BLIS) production in Aeromonas hydrophila water isolates. FEMS Microbiol Lett. 2003; 220:121-125.

107. Longeon A, Peduzzi J, Barthelemy M, et. al. Purification and Partial Identification of Novel Antimicrobial Protein from Marine Bacterium Pseudoalteromonas Species Strain X153. Mar Biotechnol. 2004; 6:633-641.
108. Ruiz-Ponte C, Samain JF, Sànchez JL, Nicolas JL. The Benefit of a Roseobacter Species on the Survival of Scallop Larvae. Mar Biotechnol. 1999; 1:52-59.

109. Balko OI, Avdeeva LV, Balko OB. Depositary Function of Pseudomonas aeruginosa Biofilm on Media with Different Carbon Source Concentration. Mikrobiol Z. 2018: 80(6):15-27.

110. Laxmi M, Kurian NK, Smitha S, Bhat SG. Melanin and bacteriocin from marine bacteria inhibit biofilms of foodborne pathogens. Ind J Biotech. 2016; 15(3): 392-399.

111. Savchenko DS, Balko OB, Balko OI, Avdieyeva LV, Yaroshenko LV, Chekman IS, Voronin YaP. [Effect of nanocomposite highly dispersed silica with silver nanoparticles on biofilm and plankton forms of Pseudomonas aeruginosa UKM B-1]. Pharm review. 2013; 27(3):35-40. Ukrainian.

112. Sharma D, Misba L, Khan AU. Antibiotics versus biofilm: an emerging battleground in microbial communities. Antimicrob Resist Infect Control $2019 ; 8: 76-86$.

113. Pisarenko PO, Balko OB. [Impact of cultivation conditions on emission rates of bacteriocin-like substances Pseudomonas aeruginosa within biofilm]. Scientific works of NUFT. 2013; 50:51-54. Ukrainian

114. Balko AB, Avdeeva LV. [Influence of temperature factor on peculiarities of Pseudomonas aeruginosa biofilm formation]. Medicine today and tomorrow. 2009; 3-4:23-27. Ukrainian.

115. Balko AB, Avdeeva LV. [Structural components and peculiarities of Pseudomonas aeruginosa biofilm organization]. Mikrobiol Z. 2010; 72(4):28-33. Ukrainian.

116. Balko OI, Avdeeva LV, Balko OB. [Stages of Pseudomonas aeruginosa biofilm formation]. Ukrain Food J. 2013; 2(1):23-26. Ukrainian.

117. Balko AB, Balko OI, Avdeeva LV. [Biofilm formation by Pseudomonas aeruginosa strains of Ukrainian collection of microorganisms]. Mikrobiol Z. 2013; 75(2):50-56. Russian. 
118. Balko OI, Balko OB, Yaroshenko LV, Skorik MA, Avdeeva LV. [Resistance of Pseudomonas aeruginosa UCM B-1 population to silver nanoparticles at early stages of biofilm formation]. Mikrobiol Z. 2017; 79(6):71-81. Ukrainian.

119. Pat. 89508 UA, MPK C12Q 1/24 Method of viable microorganisms quantity definition in the biofilm composition. Balko OI, Balko AB, Avdeeva LV. Publ. 25.04.14, Bull. № 8.
120. Pat. 89509 UA, MPK C12Q 1/24 Method of biofilm forming capacity definition in microorganisms. Balko OI, Balko AB, Avdeeva LV. Publ. 25.04.14, Bull. № 8 .

Received 15.01.2020 